\title{
Bioanalytical method development and validation for determination of metoprolol tartarate and hydrochlorothiazide using HPTLC in human plasma
}

\author{
Ambadas Ranganath Rote*, Poonam Ramdas Sonavane \\ Department of Pharmaceutical Chemistry, MGV's Pharmacy College, India
}

\begin{abstract}
A simple, sensitive, rapid and economic chromatographic method has been developed for determination of metoprolol tartarate and hydrochlorothiazide in human plasma using paracetamol as an internal standard. The analytical technique used for method development was high-performance thin-layer chromatography. HPTLC Camag with precoated silica gel Plate $60 \mathrm{~F}_{254}(20 \mathrm{~cm} \times 10 \mathrm{~cm})$ at $250 \mu \mathrm{m}$ thicknesses (E. Merck, Darmstadt, Germany) was used as the stationary phase. The mobile phase used consisted of chloroform: methanol: ammonia (9:1:0.5v/v/v). Densitometric analysis was carried out at a wavelength of $239 \mathrm{~nm}$. The rf values for hydrochlorothiazide, paracetamol and metoprolol tartarate were $0.13 \pm 0.04,0.28 \pm 0.05$, $0.48 \pm 0.04$, respectively. Plasma samples were extracted by protein precipitation with methanol. Concentration ranges of 200, 400,600,800,1000, $1200 \mathrm{ng} / \mathrm{mL}$ and 2000, 4000, 6000, 8000, 10000, $12000 \mathrm{ng} / \mathrm{mL}$ of hydrochlorothiazide and metoprolol tartarate, respectively, were used with plasma for the calibration curves. The percent recovery of metoprolol tartarate and hydrochlorothiazide was found to be 77.30 and $77.02 \%$, respectively. The stability of metoprolol tartarate and hydrochlorothiazide in plasma were confirmed during three freeze-thaw cycles $\left(-20^{\circ} \mathrm{C}\right)$ on a bench for 24 hours and post-preparatively for 48 hours. The proposed method was validated statistically and proved suitable for determination of metoprolol tartarate and hydrochlorothiazide in human plasma.
\end{abstract}

Uniterms: High performance thin layer chromatography/quantitative analysis. Metoprolol tartarate/ determination in plasma. Hydrochlorothiazide/determination in plasma. Human plasma/quantitative analysis. Protein precipitation.

\begin{abstract}
Um método simples, sensível, rápido e econômico empregando a cromatografia em camada delgada de alta eficiência (HPTLC) foi desenvolvido para determinação do tartarato de metoprolol e hidroclorotiazida em plasma humano, usando paracetamol como padrão interno. Placas prontas de sílica-gel $60 \mathrm{~F}_{254}$ $(20 \mathrm{~cm} \times 10 \mathrm{~cm}), 250 \mu \mathrm{m}$ de espessura, para HPTLC Camag (E. A Merck, Darmstadt, Alemanha) foramutilizadas como fase estacionária. A fase móvel utilizada consistiu de clorofórmio: metanol: amônia $(9: 1: 0,5 \mathrm{v} / \mathrm{v} / \mathrm{v})$. A análise densitométrica foi realizada no comprimento de onda $239 \mathrm{~nm}$. Os valores de Rf de hidroclorotiazida, paracetamol e tartarato de metoprolol foram $0.13 \pm 0.04,0.28 \pm 0.05,0.48 \pm 0.04$ respectivamente. As proteínas do plasma foram extraídas por precipitação com metanol. Para construção das curvas de calibração, empregaram-se intervalos de concentração de 200, 400, 600, 800, 1000, $1200 \mathrm{ng} / \mathrm{mL}$ e 2000, 4000, 6000, 8000, 10000, $12000 \mathrm{ng} / \mathrm{mL}$ de hidroclorotiazida e tartarato de metoprolol, respectivamente. Os percentuais de recuperação do tartarato de metoprolol e de hidroclorotiazida foram de 77,30 e 77,02, respectivamente. A estabilidade do tartarato de metoprolol e de hidroclorotiazida no plasma foi confirmada durante três ciclos de congelamento e descongelamento $\left(-20^{\circ} \mathrm{C}\right)$, durante 24 horas e póspreparação durante 48 horas. O método proposto foi validado estatisticamente, sendo adequado para determinação do tartarato de metoprolol e hidroclorotiazida em plasma humano.
\end{abstract}

Unitermos: Cromatografia em camada delgada de alta eficiência/análise quantitativa. Tartarato de metoprolol/determinação em plasma. Hidroclorotiazida/determinação em plasma. Plasma humano/ análise quantitativa. Precipitação de proteínas.

\footnotetext{
*Correspondence: A. R. Rote. Department of Pharmaceutical chemistry, MGV's Pharmacy College, Panchavati, Nashik 422 003, India. E-mail: rotembadas@gmail.com
} 


\section{INTRODUCTION}

Chemically, hydrochlorothiazide (Figure 1) is 6-chloro-3,4-dihydro-2H-1,2,4-benzothiadiazine-7sulphonamide-1,1-dioxide and metoprolol tartarate is 1-[4-(2-methoxyethyl)phenoxy]-3-(propan-2-ylamino) propane-2-ol. Hydrochlorothiazide (HCTZ) is one of the oldest thiazide diuretics used to treat hypertension. It is often prescribed in combination with other antihypertensive drugs such as $\beta$-blockers, angiotensin converting enzyme inhibitors, or angiotensin II receptor blockers (Wellington, 2002). A combination dosage form of HCT with the $\beta 1$-selective (cardio selective) $-\beta$-blocker Metoprolol tartarate (MET) (Smilide, 1983), is more effective than either drug alone in the management of hypertension and is effective in patients unresponsive to immunotherapy with either agent (Papademetriou et al., 2006; Hainer, 2007). For the determination of MET in human plasma, several methods based on high performance liquid chromatography (HPLC) with UV (Aqil et al., 2007) and fluorescence (Zhaing, 2006) detection, gas chromatography-mass spectrometry (Yilmaz, 2009) and LC-MS/MS (Gowda et al., 2007; Gao et al., 2010) have been reported. Similarly, a method for the determination of HCT in human plasma has been developed based on HPLC with UV or diode array detection (Zendelovska, 2004; Erk, 2003) and LC-MS/MS (Ramakrishna et al., 2005; Liu et al., 2007). No HPTLC method has been developed for determination of metoprolol tartarate and hydrochlorothiazide in human plasma by protein precipitation. Therefore, we developed a new simple, sensitive, rapid and economic high-performance thin-layer chromatographic method for determination of metoprolol tartarate and hydrochlorothiazide in human plasma by protein precipitation using paracetamol as an internal standard.

We preferred HPTLC over HPLC because the former method is useful for simultaneous processing of sample and standard, allowing better analytical precision and accuracy, several analysts to work simultaneously, and shorter analysis time as well as offering lower cost per analysis, low maintenance cost, simple sample preparation, handling of samples of divergent nature, no prior treatment for solvents such as filtration and degassing, low mobile phase consumption per sample, no interference from previous analysis, fresh stationary and mobile phases for each analysis, no contamination, visual detection, an open system, on UV-absorbing compounds detected by post-chromatographic derivatization.

\section{MATERIAL AND METHODS}

\section{Instrumentation}

HPTLC Camag with precoated silica gel Plate $60 \mathrm{~F} 254(20 \mathrm{~cm} \times 10 \mathrm{~cm})$ at $250 \mu \mathrm{m}$ thicknesses (E. Merck, Darmstadt, Germany) was used as the stationary phase. Sample application was done by using a Camag $100 \mu \mathrm{L}$ syringe and Camag Linomat $\mathrm{V}$ applicator. The sample was sprayed in the form of narrow bands of $8 \mathrm{~mm}$ length at a constant rate of $2 \mu \mathrm{L} / \mathrm{s}$. Linear ascending development was carried out in a $20 \mathrm{~cm} \times 10 \mathrm{~cm}$ twin trough glass chamber (Camag, Muttenz, Switzerland). The densitometric scanning was performed by using Camag TLC scanner III

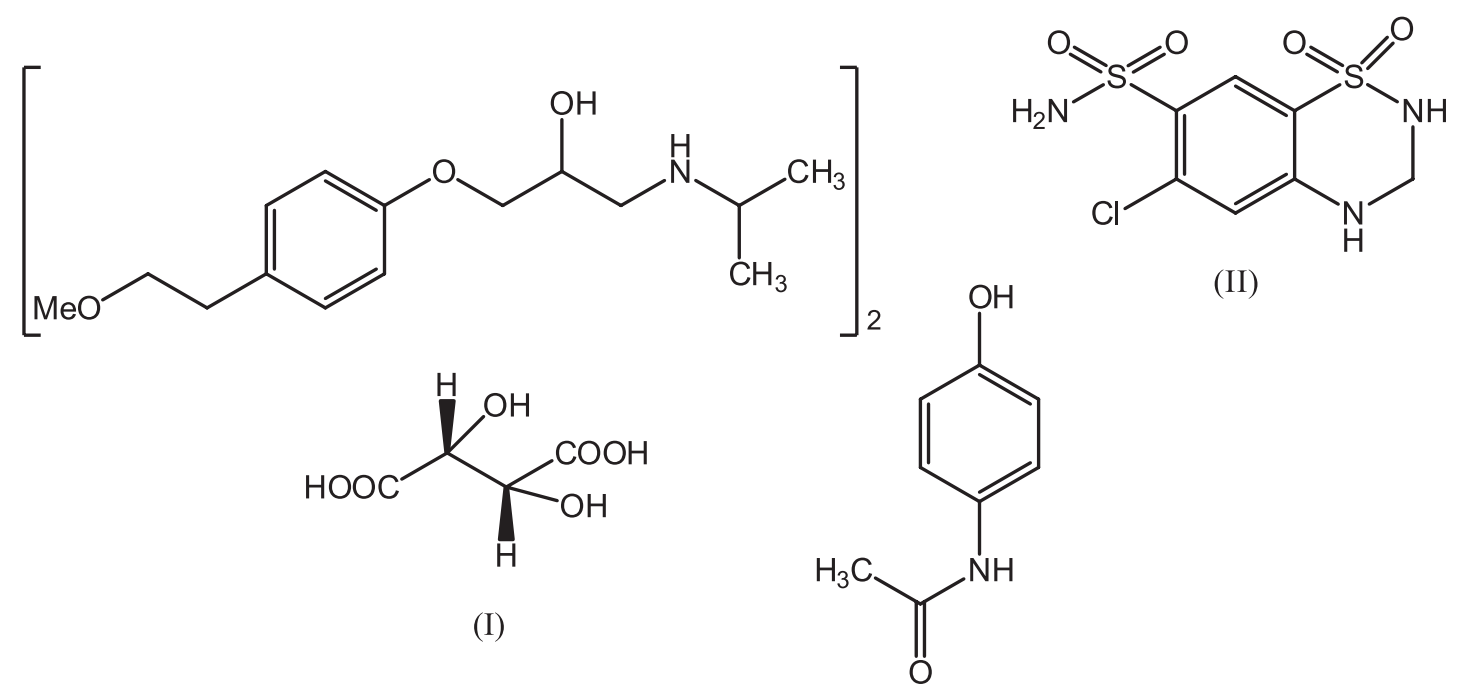

(III)

FIGURA 1 - Structure of metoprolol tartarate (I), hydrochlorothiazide (II) and paracetamol (IS) (III). 
supported by win CATS software (V 1.4.2.8121 Camag). Evaluation of the chromatogram was done by using peak areas.

\section{Chemicals}

Metoprolol tartarate (Ajanta Pharmaceuticals, Mumbai, Maharashtra, India), hydrochlorothiazide (Elder pharmaceuticals, Mumbai, Maharashtra, India) and paracetamol (Kirti Pharmachem Ltd., Sinner, Maharashtra, India) had 99.80\%, 98.70\% and 100.1\% purity, respectively. These were used as received without checking their purity. The HPLC grade methanol and Analytical Reagent grade Chloroform were purchased from s d Fine Chem. Ltd., Mumbai, India. The human plasma used for the research work was supplied by Arpan Blood Bank, Nashik, Maharashtra, India.

\section{Preparation of stock solution and working standard solution}

Stock solutions of $1.0 \mathrm{mg} / \mathrm{mL}$ each of metoprolol tartarate, hydrochlorothiazide and paracetamol were prepared in methanol.

\section{Preparation of plasma sample}

For HPTLC, in a $15 \mathrm{~mL}$ centrifuge tube, $2,4,6,8,10$, $12 \mu \mathrm{L}$ of working stock solution of hydrochlorothiazide was added to drug-free plasma to provide calibration standards of $200,400,600,800,1000,1200 \mathrm{ng} / \mathrm{mL}$ while $20,40,60,80,100,120 \mu \mathrm{L}$ of working stock solution of metoprolol tartarate was added to drug-free plasma to provide calibration standards of $2000,4000,6000,8000$, $10000,12000 \mathrm{ng} / \mathrm{mL}$ and $1000 \mathrm{ng} / \mathrm{mL}$ of paracetamol (internal standard) and kept constant. The quality control (QC) samples were prepared in plasma in the concentration range of 400, 800, and $1200 \mathrm{ng} / \mathrm{mL}$ and 4000, 8000, and $12000 \mathrm{ng} / \mathrm{mL}$. Protein precipitation and extraction was carried out by using methanol $3 \mathrm{~mL}$ and acetonitrile $0.1 \mathrm{~mL}$ by vigorous vortex mixing using a Remi mixer for $1 \mathrm{~min}$ and centrifuging at 5,000 rpm for $10 \mathrm{~min}$. The organic phase was recovered and evaporated to dryness on a hot plate. The residual mass was reconstituted with $1 \mathrm{~mL}$ methanol. The analysis was carried using HPTLC.

\section{Chromatographic conditions}

Mobile phase was selected as a mixture of chloroform, methanol and ammonia in the ratio of $(9.0: 1.0: 0.5, \mathrm{v} / \mathrm{v} / \mathrm{v})$ for the development of plates. Time for chamber saturation was optimized to $30 \mathrm{~min}$. The length of chromatographic development was $70 \mathrm{~mm}$. The densitometric scanning was performed at $239 \mathrm{~nm}$.

\section{Method validation}

The method was validated for sensitivity, selectivity, precision, accuracy, linearity, recovery and stability. The validation of the method was based on FDA guidelines and on standard Bioanalytical method validation recommendations. The selectivity of the method was investigated by analyzing six blank plasma samples. Each blank sample was tested for interference using the proposed extraction procedure. Five replicates of three QC samples (low, mid and high) were used for the determination of precision and accuracy. Intra-day and inter-day precision were carried out. Precision and accuracies showed $15 \%$ relative standard deviation (RSD) from nominal values and at LLOQ these were both $20 \%$. The recovery of metoprolol tartarate and hydrochlorothiazide was calculated by comparing the peak areas of low, mid, and high quality control sample $(400,800,1200 \mathrm{ng} / \mathrm{mL}$ and $4000,8000.12000 \mathrm{ng} / \mathrm{mL}$, respectively) prepared in plasma (extracted) with unextracted metoprolol tartarate and hydrochlorothiazide, respectively.

Stability experiments were undertaken to detect degradation of Metoprolol tartarate and hydrochlorothiazide under specific conditions. Freezethaw stability was determined at two QC concentrations (low, high) after freezing $\left(-20{ }^{\circ} \mathrm{C}\right)$ and thawing for three cycles and compared with the nominal value. Bench-top stability was assessed for low and high QC samples by comparing with the nominal value which was stored at room temperature for $12 \mathrm{~h}$. The effect of storage within the auto-sampler was assessed by comparing QC samples injected immediately after preparation with those left in the auto-sampler for $48 \mathrm{~h}$.

\section{RESULT AND DISCUSSION}

\section{Extraction procedure optimization}

One of the most difficult parts during the method development was to achieve high and reproducible recovery from the solvent used for extraction of the drug. Different solvents were tried for the extraction of metoprolol tartarate and hydrochlorothiazide from human plasma. First, $3 \mathrm{~mL}$ each of chloroform and toluene were tried for the precipitation of plasma but the recovery proved very low. It yielded $55-75 \%$ recovery because of less precipitation of protein from plasma. Finally, 
methanol was tried and $70-80 \%$ recovery obtained. It was found that the addition of acetonitrile $(0.1 \mathrm{~mL})$ increased the precipitation of protein and also the recovery which was reproducible and high as compared to other solvents. Thus, methanol and acetonitrile $(3.0 \mathrm{~mL}: 0.1 \mathrm{~mL})$ was kept as the final solvent for extraction of hydrochlorothiazide and metoprolol tartarate. Recovery was done in plain extracting solvent from human plasma.

\section{Optimization of chromatographic conditions}

Initially, plain solvents such as methanol, ethyl acetate, chloroform, toluene, acetone were tried. The spots were developed with chloroform and methanol but no proper resolution observed among hydrochlorothiazide, metoprolol tartarate and paracetamol, also showing the tailing. Subsequently, chloroform and methanol at the ratio of $(8: 2, \mathrm{v} / \mathrm{v})$ was tried but again no proper resolution was obtained. The proportion of chloroform was then increased and of methanol decreased by $1 \mathrm{~mL}$, showing good resolution. Lastly, the addition of Ammonia solution at $0.5 \mathrm{~mL}$ helped to reduce the tailing effect and good resolution with symmetrical peaks of hydrochlorothiazide, paracetamol and metoprolol tartarate were obtained. Finally, the mobile phase used consisted of chloroform: methanol: Ammonia (9:1: 0.5, v/v/v) which allowed good resolution of peaks for hydrochlorothiazide, metoprolol tartarate and paracetamol. The $\mathrm{R}_{\mathrm{f}}$ values for hydrochlorothiazide, paracetamol and metoprolol tartarate were found to be $0.13 \pm 0.04,0.28 \pm 0.05$ and $0.48 \pm 0.04$, respectively. Well-defined spots were obtained by prewashing the plate using methanol followed by activating at $120^{\circ} \mathrm{C}$ for $20 \mathrm{~min}$. The chamber was saturated with mobile phase for $25 \mathrm{~min}$ at room temperature, yielding reproducible $\mathrm{R}_{\mathrm{f}}$ values for hydrochlorothiazide, paracetamol and metoprolol tartarate, respectively (Figure .2).

\section{Calibration curves}

A six-point calibration curve was constructed by plotting the peak response ratio of hydrochlorothiazide to paracetamol versus concentration of hydrochlorothiazide and metoprolol tartarate to paracetamol versus concentration of metoprolol tartarate in plasma. Correlation coefficients were 0.9979 and 0.9954 for hydrochlorothiazide and metoprolol tartarate, respectively. Linearities were found over the range $2-12 \mu \mathrm{L} / \mathrm{mL}$ and $20-120 \mu \mathrm{L} / \mathrm{mL}$ for hydrochlorothiazide and metoprolol tartarate, respectively. The lower limit of quantification was defined as the lowest concentration in the calibration curve. The hydrochlorothiazide and metoprolol tartarate can be determined at LLOQ $2 \mu \mathrm{L} / \mathrm{mL}$ and $20 \mu \mathrm{L} / \mathrm{mL}$.

\section{Recovery}

Absolute recovery was calculated by comparing peak areas obtained from freshly prepared sample extracted with unextracted standard solutions of the same concentration. Recovery data was determined in triplicates at three concentrations (low, mid, high) as recommended by the FDA guidelines (US Department, 2001). The

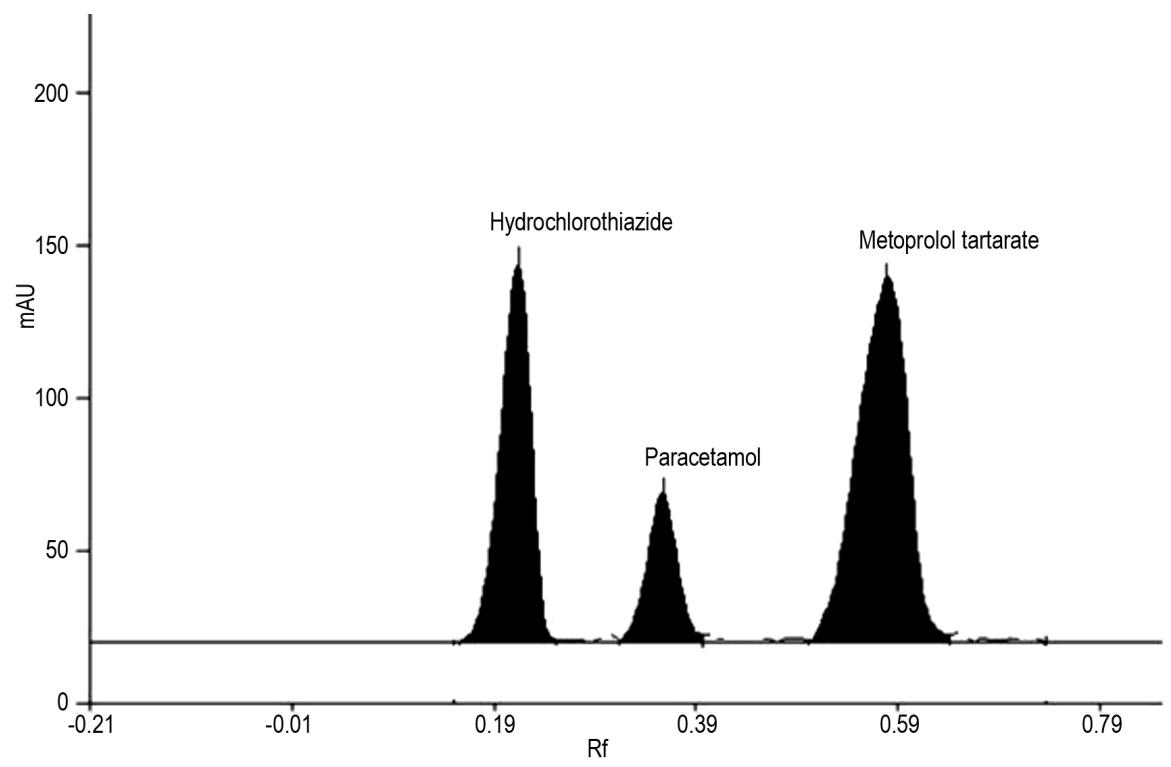

FIGURE 2 - Densitogram of hydrochlorothiazide $(\operatorname{Rf}(0.13 \pm 0.04)$, paracetamol $\operatorname{Rf}(0.28 \pm 0.05)$ and metoprolol tartarate $\operatorname{Rf}(0.48 \pm 0.04)$. 
recoveries of hydrochlorothiazide and metoprolol tartarate for HPTLC recovery at the three concentrations 400, 800 , $1200 \mathrm{ng} / \mathrm{mL}$ and 4000, 8000, $12000 \mathrm{ng} / \mathrm{mL}$ were found to be $77.33,74.65,79.94 \%$ and $70.59,84.91,75.57 \%$, respectively (Table I).

TABLE I - Result of recovery of hydrochlorothiazide and metoprolol tartarate in human plasma

\begin{tabular}{lcccccc}
\hline \multirow{2}{*}{ Sr. No. } & \multicolumn{2}{c}{ Concentration } & \multicolumn{2}{c}{ Recovery } & \multicolumn{2}{c}{ \%RSD } \\
\cline { 2 - 7 } & HCTZ & MET & HCTZ & MET & HCTZ & MET \\
\hline 1 & 400 & 4000 & 77.33 & 70.59 & 7.92 & 11.2 \\
2 & 800 & 8000 & 74.65 & 84.91 & 7.32 & 4.5 \\
3 & 1200 & 12000 & 79.94 & 75.57 & 4.9 & 3.8 \\
\hline
\end{tabular}

\section{Precision and accuracy}

Precision of the method was determined by repeatability (intraday) and intermediate precision (interday) and accuracy for a set of quality control (QC) samples (low, mid, high) in replicate $(\mathrm{n}=5)$. The inter-day and intraday precision and accuracy for the hydrochlorothiazide and metoprolol tartarate evaluated by assaying the QC samples (low, mid, high) $(\mathrm{n}=5)$ were expressed in $(\% \mathrm{RSD})$. In this assay, the intra-run precision was found to be in the range of $0.53-3.17 \%$ and $1.29-4.24 \%$ whereas the inter-run precision was $1.2-1.51 \%$ and $1.43-1.7 \%$. The accuracy was within $1.10-2.67 \%$. The above values were within the acceptable range, showing that the methods are accurate and precise. The low percent relative standard deviation (\%RSD) and percent relative error $(\% \mathrm{RE})$ were within acceptable limits. The results of inter-day, intra-day precision, and accuracy for the hydrochlorothiazide and metoprolol tartarate are shown in Table II.

\section{Sensitivity and selectivity}

Selectivity or specificity should be assessed to show that the intended analytes are measured and that their quantitation is not affected by the presence of the biological matrix. For the HPTLC method by protein precipitation, as shown in Figure 3, there was no interference by the biological matrix in the quantitation of hydrochlorothiazide and metoprolol tartarate. There were no changes in the retention factor of hydrochlorothiazide and metoprolol tartarate, where the method proved selective. Sensitivity of the method is defined as the lowest concentration that can be measured with an acceptable limit of accuracy and precision which is lower than 20\% (Bansal, 2007). The accuracy and precision at the lower limit of quantitation (LLOQ) was analyzed by using five replicates $(n=5)$ of the sample at the LLOQ concentration. The accuracy was determined by $\% \mathrm{RE}$ at this LLOQ concentration. The lower limits of quantitation detected were found to be $200 \mathrm{ng} / \mathrm{mL}$ and $2000 \mathrm{ng} / \mathrm{mL}$ with $\% \mathrm{RE}=17.8,13.43$ and $\% \mathrm{RSD}=10.74,4.11$ for hydrochlorothiazide and metoprolol tartarate, lying within the acceptable limit.

\section{Stability}

In bench-top stability, the low and high QC sample were thawed and left at room temperature for $12 \mathrm{~h}$. Comparison of the results for the QC sample (low and high) with freshly prepared stock solution showed that there was no significant difference between response of freshly prepared solution and sample of hydrochlorothiazide and metoprolol tartarate after $12 \mathrm{~h}$. Freeze-thaw stability was determined after two freeze-thaw cycles for three replicates of low and high QC samples. The samples were stored at $-20 \circ \mathrm{C}$ temperature for $24 \mathrm{~h}$. They were then thawed at room temperature. No significant difference between freeze-thaw samples and freshly prepared samples was observed. The result of stability experiments showed that no significant degradation occurred at ambient temperature for $48 \mathrm{~h}$ for post-preparative stability. Results of stability for the HPTLC method are shown in Table III.

TABLE II - Results of precision of hydrochlorothiazide and metoprolol tartarate in human plasma

\begin{tabular}{lcccccc}
\hline \multirow{2}{*}{ Precision } & \multicolumn{2}{c}{ Concentration $(\mathrm{ng} / \mathrm{mL})$} & \multicolumn{3}{c}{ \%RSD } & \multicolumn{2}{c}{ \%RE } \\
\cline { 2 - 7 } & HCTZ & MET & HCTZ & MET & HCTZ & MET \\
\hline \multirow{3}{*}{ INTRA } & 400 & 4000 & 2.09 & 1.20 & 6.37 & 4.55 \\
& 800 & 8000 & 0.55 & 0.92 & 14.69 & 10.01 \\
& 1200 & 12000 & 1.57 & 1.24 & 7.10 & 9.76 \\
INTER & 400 & 4000 & 4.80 & 2.43 & 6.88 & 11.44 \\
& 800 & 8000 & 2.44 & 7.14 & 15.82 & 12.53 \\
\hline
\end{tabular}


TABLE III - Stability study of metoprolol tartarate and hydrochlorothiazide in human plasma

\begin{tabular}{|c|c|c|c|c|c|c|}
\hline \multirow{2}{*}{ Parameters } & \multicolumn{2}{|c|}{ Concentration $(\mathrm{ng} / \mathrm{mL})$} & \multicolumn{2}{|c|}{ S.D } & \multicolumn{2}{|c|}{$\% \mathrm{RE}$} \\
\hline & HCTZ & MET & HCTZ & MET & HCTZ & MET \\
\hline \multicolumn{7}{|c|}{ Freeze-thaw stability } \\
\hline Low & 200 & 2000 & 16.96 & 55.73 & 7.14 & 14.08 \\
\hline High & 1200 & 12000 & 44.60 & 301.67 & 10.36 & 9.01 \\
\hline \multicolumn{7}{|c|}{ Bench-top stability } \\
\hline Low & 200 & 2000 & 4.86 & 81.95 & 5.23 & 12.76 \\
\hline High & 1200 & 12000 & 60.20 & 439.23 & 7.30 & 15.25 \\
\hline \multicolumn{7}{|c|}{ Post-preparative stability } \\
\hline Low & 200 & 2000 & 2.12 & 33.24 & 3.18 & 9.03 \\
\hline High & 1200 & 12000 & 16.69 & 80.18 & 4.69 & 9.91 \\
\hline
\end{tabular}

\section{CONCLUSION}

The proposed HPTLC method for the estimation of metoprolol tartarate and hydrochlorothiazide in human plasma by protein precipitation is both selective and sensitive. The sensitivity of the method is suitable for handling various plasma levels of the drug. The method is economical and faster than previously published methods.

\section{ACKNOWLEDGEMENT}

The authors are thankful to the Management and Principal Dr. Rajendra S. Bhambar, M. G. V.'s Pharmacy College, Nashik, for providing the necessary facilities for the research work. The authors are also thankful to Arpan Blood Bank, Nashik, for providing human plasma and to Ajanta Pharma Ltd., Mumbai, Maharashtra, India, for providing metoprolol tartarate, to Elder pharmaceuticals, Mumbai, Maharashtra, India, for providing hydrochlorothiazide and for the paracetamol from Kirti Pharmachem, Sinner, Maharashtra, India, donated as a gift sample for the research work.

\section{REFERENCES}

AQIL, M.; ALI, A.; AHAD, A.; SULTANA, Y.; NAJMI, A.K.; SAHA, N.A validated HPLC method for estimation of metoprolol in human plasma. Acta Chromatogr., v.19, p.130-140, 2007.

BANSAL, S.; DESTEFANO, A. Key elements of bioanalytical method validation for small molecules. AAPS J., v.9, p.E109-E114, 2007.
ERK, N. Simultaneous determination of irbesartan and hydrochlorothiazide in human plasma by liquid chromatography. J. Chromatogr. B., v.784, p.195-201, 2003.

FOOD AND DRUG ADMINISTRATION. FDA. Guidance for Industry: bioanalytical method validation. Rockville: US Department of Health and Human Services, 2001. p.1-26.

GAO, F.; ZHANG, M.; CUI, X.; WANG, Z.; SUN Y, G.J. Simultaneous quantitation of hydrochlorothiazide and metoprolol in human plasma by liquid chromatographytandem mass spectrometry. J. Pharm. Biomed. Anal., v.52, p.149-154, 2010.

GOWDA, K.V.; MANDAL, U.; SENTHAMIL, S.P.; SOLOMON, W.D.S.; GHOSH, A.; SARKAR, A.; AGARWAL, S.; RAO, T.N.; PAL, T.K. Liquid chromatography tandem mass spectrometry method for simultaneous determination of metoprolol tartrate and ramipril in human plasma. $J$. Chromatog. B, v.858, p.13-21, 2007.

HAINER, J.W.; SUGG, J. Metoprolol succinate extended release/hydrochlorothiazide combination tablets. Vasc. Health Risk Manag, v.3, p.279-288, 2007.

LIU, F.; XU, Y.; GAO, S.; ZHANG, J.; GUO, Q. Determination of hydrochlorothiazide in Human plasma by liquid chromatography/tandem mass spectrometry. J. Pharm. Biomed. Anal., v.44, p.1187-1191, 2007.

PAPADEMETRIOU, V.; HAINER, J.W.; SUGG, J.; MUNZER, D. Factorial antihypertensive study of an extended-release metoprolol and hydrochlorothiazide combination. Am. J. Hypertens., v.19, p.1217-1225, 2006. 
RAMAKRISHNA, N.V.; VISHWOTTAM, K.N.; MANOJ, S.; KOTESHWARA, M; SMILDE, J.G. Comparison of the antihypertensive effect of a double dose of metoprolol versus the addition of hydrochlorothiazide to metoprolol. Eur. J. Clin. Pharmacol., v.25, p.581-583, 1983.

WELLINGTON, K.; FAULDS, D.M. Valsartan/ hydrochlorothiazide: a review of its pharmacology, therapeutic efficacy and place in the management of hypertension. Drugs, v.62, p.1983-2005, 2002.

WISHU, S.; VARMA, D.P. Sensitive liquid chromatographytandem mass spectrometry method for quantification of hydrochlorothiazide in human plasma. Biomed. Chromatogr., v.19, p.751-760, 2005.
YILMAZ, B.; ARSLAN, S.; AKBA, V. Gas chromatographymass spectrometry method for determination of metoprolol in the patients with hypertension. Talanta, v.80, p.346-351, 2009.

ZENDELOVSKA, D.; STAFILOV, T.; MILOSEVSKI, P. Development of solid-phase extraction method and its application for determination of hydrochlorothiazide in human plasma using HPLC. Biomed. Chromatogr., v.18, p.71-76,2004.

ZHANG, Y.; WU, H.L.; XIA, A.L.; ZHU, S.H.; HAN, Q.J.; YU, R.Q. Fluorescence determination of metoprolol in human plasma by trilinear decomposition-based calibration techniques. Anal. Bioanal. Chem, v.386, p.1741-1748, 2006.

Received for publication on $04^{\text {th }}$ December 2011 Accepted for publication on $06^{\text {th }}$ June 2012 